\title{
Land Subsidence in the Southwestern Mojave Desert, California, 1992-2009
}

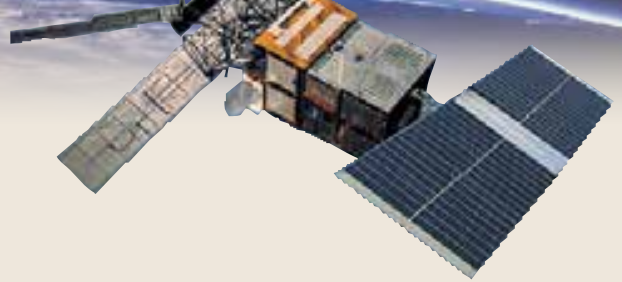

In cooperation with the Mojave Water Agency (MWA), the U.S. Geological Survey (USGS) has been monitoring land subsidence in the southwestern Mojave Desert of California using satellite Interferometric Synthetic Aperture Radar (InSAR) combined with ground-based techniques. Maps of land subsidence constructed from the InSAR data have proven to be an economical means to evaluate subsidence-with the goal of identifying small problems before they become large ones. The maps of subsidence over the considerably large (nearly 5,000 square miles [mi²]) MWA management area (fig. 1) enabled researchers to detect small magnitude, localized areas of subsidence near five lakebeds.

\section{Introduction and Background}

Groundwater has been the primary source of domestic, agricultural, and municipal water supplies in the southwestern Mojave Desert, California, since the early 1900s. Increased demands on water supplies have caused groundwater-level declines of more than $100 \mathrm{feet}(\mathrm{ft})$ in some areas of this desert (fig. 2 inset) between the 1950s and the 1990s (Stamos and others, 2001; Sneed and others, 2003). These water-level declines have caused the aquifer system to compact, resulting in land subsidence. Differential land subsidence (subsidence occurring at different rates across the landscape) can alter surface drainage routes and damage surface and subsurface infrastructure. For example, fissuring across State Route 247 at Lucerne Lake (fig. 2) has required repairs as has pipeline infrastructure near Troy Lake.

Land subsidence within the Mojave River and Morongo Groundwater Basins of the southwestern Mojave Desert has been evaluated using InSAR, ground-based measurements, geology, and analyses of water levels between 1992 and 2009 (years in which InSAR data were collected). The results of the analyses were published in three USGS reports-

Sneed and others (2003), Stamos and others (2007), and Solt and Sneed (2014).

Results from the latter two reports were

integrated with results from other USGS/MWA cooperative groundwater studies into the broader scoped USGS Mojave Groundwater Resources Web site (http://ca.water.usgs.gov/ mojave/). This fact sheet combines the detailed analyses from the three subsidence reports, distills them into a longer-term context, and provides an assessment of options for future monitoring.

\section{InSAR Reveals Localized Subsidence near Dry Lakebeds}

InSAR data and field observations reveal land subsidence during 1992-2009 in five localized areas near dry lake beds- El Mirage Lake, Harper Lake, Troy Lake, Coyote Lake, and Lucerne Lake (fig. 2). Average subsidence rates at Harper, Troy, and Coyote Lakes, were smallest at about $0.3-0.4$ inch per year (in/yr), El Mirage Lake had a slightly higher rate at nearly $0.5 \mathrm{in} / \mathrm{yr}$, and Lucerne Lake had the highest rate of about $0.6 \mathrm{in} / \mathrm{yr}$. Only two of the areas - Troy Lake and Lucerne Lake - indicated increased subsidence rates starting in the late 1990 s or early 2000 s, which may reflect changes in agricultural land use and (or) a population increase that require more water use, whereas the other three areas subsided at fairly steady rates.

Figure 1. National Agriculture Imagery Program (NAIP) imagery from 2012 overlain with dry lakebeds, Mojave Water Agency management area, and other features in the Mojave Desert, California. 


\section{El Mirage Lake}

\section{Observations}

- More than 6 inches (in.) of subsidence occurred at a fairly steady rate of nearly 0.5 in/yr during 1995-2009.

- Water levels generally declined by small to moderate amounts in shallow and deep wells during the 1990s and 2000s.

- Historical groundwater levels (prior to the 1980s) are not known, although simulations indicate water-level declines since the 1930s (Stamos and others, 2001).

- Clay layers ranging from 5 to $295 \mathrm{ft}$ in thickness are present in the shallow and deep parts of the aquifer system.

\section{Results}

- Concurrent and residual compaction throughout the aquifer system are both likely because water levels were declining and thin and thick clay layers are present.

- Historical (simulated) and current (measured) water-level declines suggest that water levels were likely at or near historically low levels, indicating that at least some of the compaction is permanent.

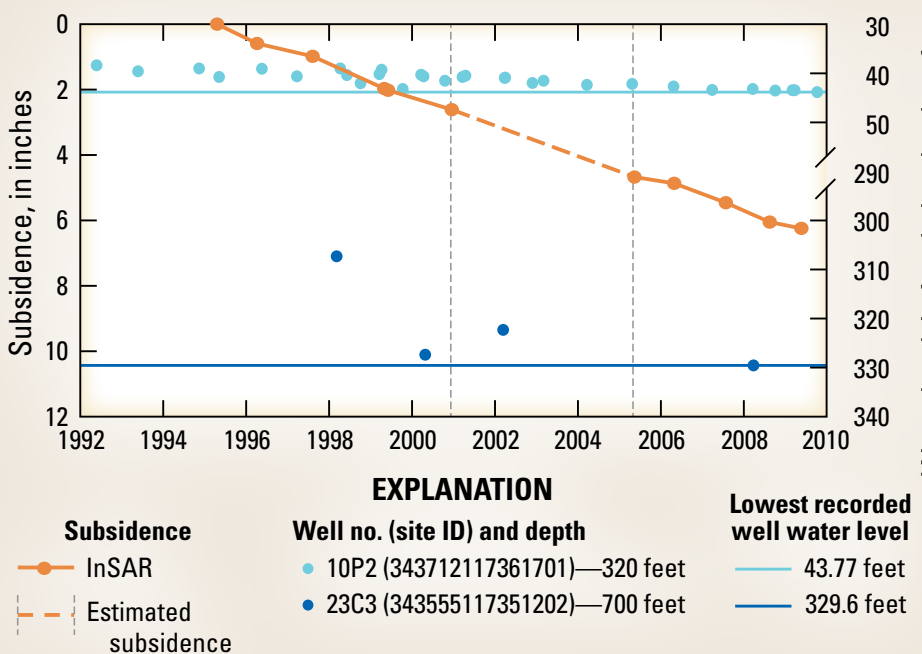

\section{Troy Lake}

\section{Observations}

- About 5 in. of subsidence occurred at an average rate of about $0.3 \mathrm{in} / \mathrm{yr}$ during 1993-2009.

- Subsidence rates increased from about $0.15 \mathrm{in} / \mathrm{yr}$ during 1993-99 to nearly 0.45 in/yr during 2004-09.

- Water levels fluctuated seasonally but declined persistently to historically low levels in shallow and deep wells since the 1950s.

- Clay layers ranging from 3 to $100 \mathrm{ft}$ in thickness are present in the shallow and deep parts of the aquifer system.

\section{Results}

- Concurrent and residual compaction throughout the aquifer system are both likely because water levels were declining and thin and thick clay layers are present.

- Persistent water-level declines in shallow and deep wells indicate that the compaction likely is permanent.

\section{Harper Lake}

\section{Observations}

- More than 6 in. of subsidence occurred at a fairly steady rate of about 0.4 in/yr during 1992-2009.

- Water levels generally declined in shallow wells to historically low levels since the 1950s, although deep wells generally recovered after reaching historically low levels in the 1980s.

- Clay layers ranging from 8 to $89 \mathrm{ft}$ in thickness are present in the shallow and deep parts of the aquifer system.

\section{Results}

- Concurrent and residual compaction in the shallow parts of the aquifer system are likely because water levels were declining and thin and thick clay layers are present.

- If compaction has occurred in the deep parts of the aquifer system, it likely is residual because water levels (at depth) were recovering and both thin and thick clay layers are present.

- At least some compaction that may have occurred in the shallow parts of the aquifer system is permanent because water levels have persistently declined.
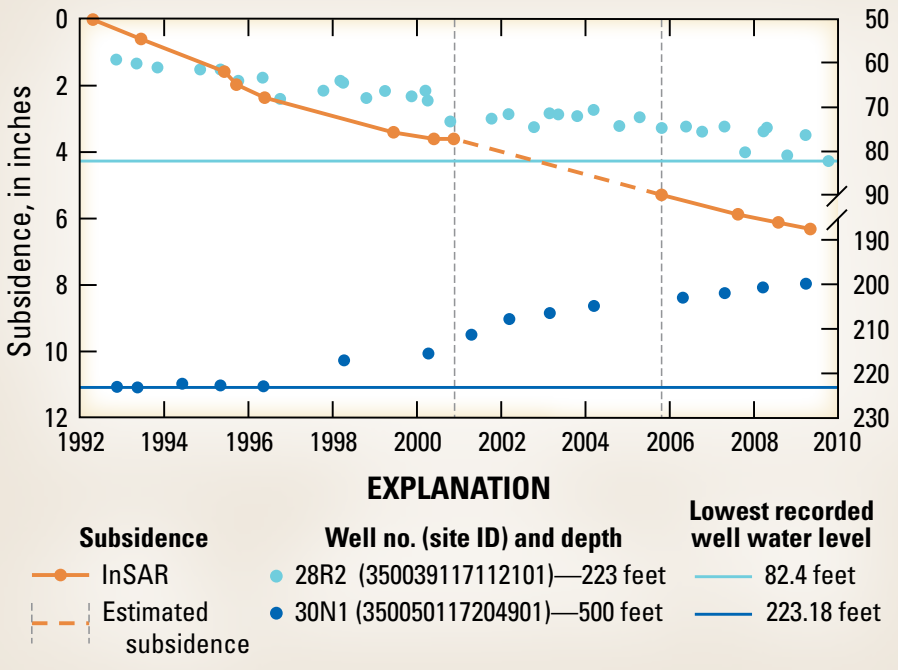


\section{Observations}

- About 2 in. of land subsidence occurred at a fairly steady rate of about $0.4 \mathrm{in} / \mathrm{yr}$ during 2004-09; subsidence was not detected prior to 2004.

- Water levels persistently declined small amounts to historically low levels throughout the aquifer system during 1992-2009.

- Historical water levels in the shallower parts of the aquifer system have declined small amounts since the 1950s; historical water levels in the deeper parts of the aquifer system are not known.

- Clay thickness is not known.

\section{Results}

- Sparse water level and lithological data hindered interpretations regarding the timing or permanence of compaction.

- The absence of substantial water-level declines in the shallower parts of the aquifer system suggests that compaction may be occurring deeper in the system.
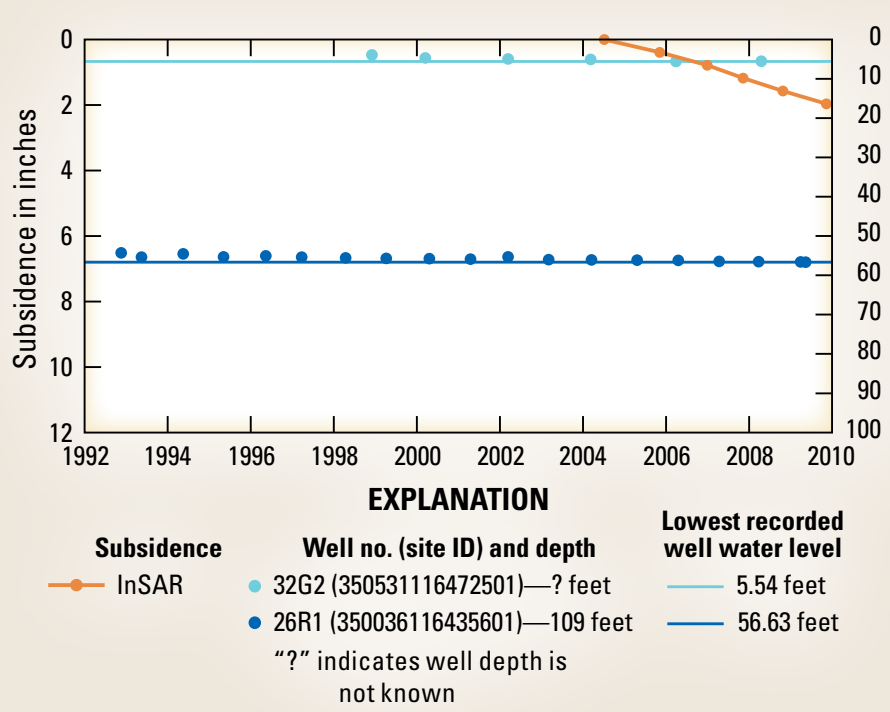

\section{Lucerne Lake}

\section{Observations:}

- Nearly 11 in. of subsidence occurred at an average rate of about 0.6 in/yr during 1992-2009.

- Subsidence rates increased from about $0.5 \mathrm{in} / \mathrm{yr}$ during 1992-99 to about 0.7 in/yr during 1999-2009.

- Water levels declined to historically low levels in shallow wells and recovered in deep wells during 1998-2009 (historical water levels at depth are not known).

- Clay ranging from 20 to $40 \mathrm{ft}$ in thickness is present in shallow parts of the aquifer system, but no clay was detected at depth.

- Fissures that trend northeast to southwest (consistent with extensional features near the margins of subsiding areas) have been observed southeast of Lucerne Lake. These fissures have caused damage to State Route 247.

Results:

- Concurrent and residual compaction in the shallow aquifer system may have occurred because of water-level declines of more than $100 \mathrm{ft}$ since the 1950s and the presence of thick, loosely compacted clay layers.

- Compaction likely has not occurred in the deeper parts of the aquifer system because of the absence of clay at depth.

- At least some compaction that may have occurred in the shallow parts of the aquifer system likely is permanent because water levels have persistently declined by more than $100 \mathrm{ft}$ to historical lows (fig. 2 inset).

- Fissures likely were caused by localized differential subsidence-more subsidence occurred to the southeast than to the northwest of the fissures.

- The largest subsidence magnitude observed in the study area coincides with the largest water-level declines where shallow and thick clay layers may be highly compressible because of less overburden from overlying sediments.

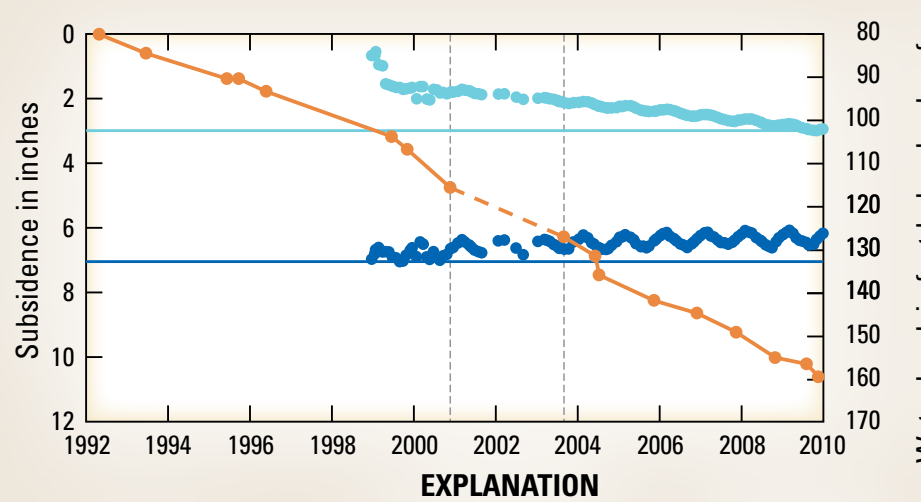

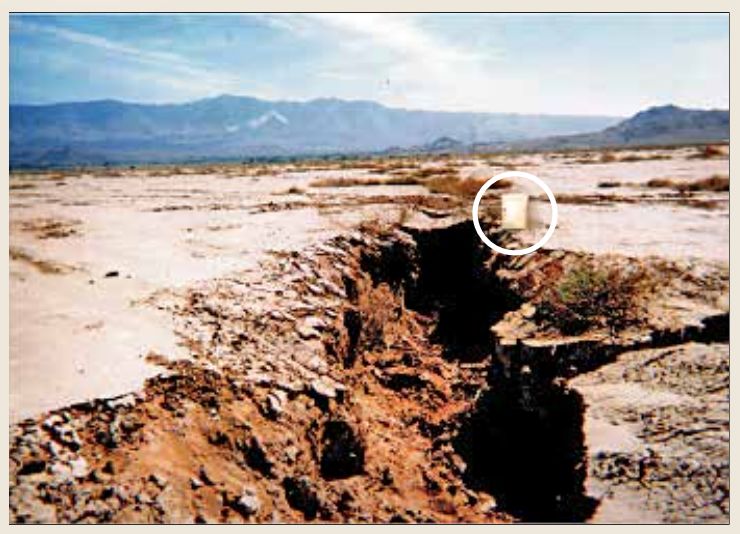

Fissures on the southeastern edge of Lucerne Lake (see figure 2 for location) in San Bernardino County, Mojave Desert, California. View to the northeast, with 5-gallon bucket (circled) for scale. Photograph by Loren Metzger, U.S. Geological Survey, May 2001. 


\section{What Caused the Localized Subsidence?}

The localized subsidence in the five areas was caused by declining water levels in fine-grained (clay and silt) sediments. In the Mojave River and Morongo Groundwater Basins (fig. 2), the combination of variable climatic conditions, tectonic activity, and other factors resulted in complex depositional patterns of clay in the subsurface, which, combined with water-level declines, define the lateral extent and magnitude of subsidence. The deposition of highly compressible paleolakebed deposits occurred at variable rates depending in part on climatic conditions. For example, wetter conditions lead to a faster pace of deposition and thus thicker clay deposits such as those at Lucerne Lake, whereas drier conditions lead to a slower pace of deposition and thinner clay deposits, typical of Troy Lake. Deposition centers migrated or oscillated in response to depositional and tectonic activity (Motts, 1969).

\section{Putting It All Together}

Subsidence caused by aquifersystem compaction can be recoverable or permanent, and even at a single location both types of compaction can occur simultaneously at different depths. Nearly all alluvial aquifer systems, where groundwater levels fluctuate, will respond by compacting and expanding small amounts that are recoverable, but fine-grained aquifer systems, where groundwater levels persistently decline past historical lows may compact permanently (Galloway and others, 1999).

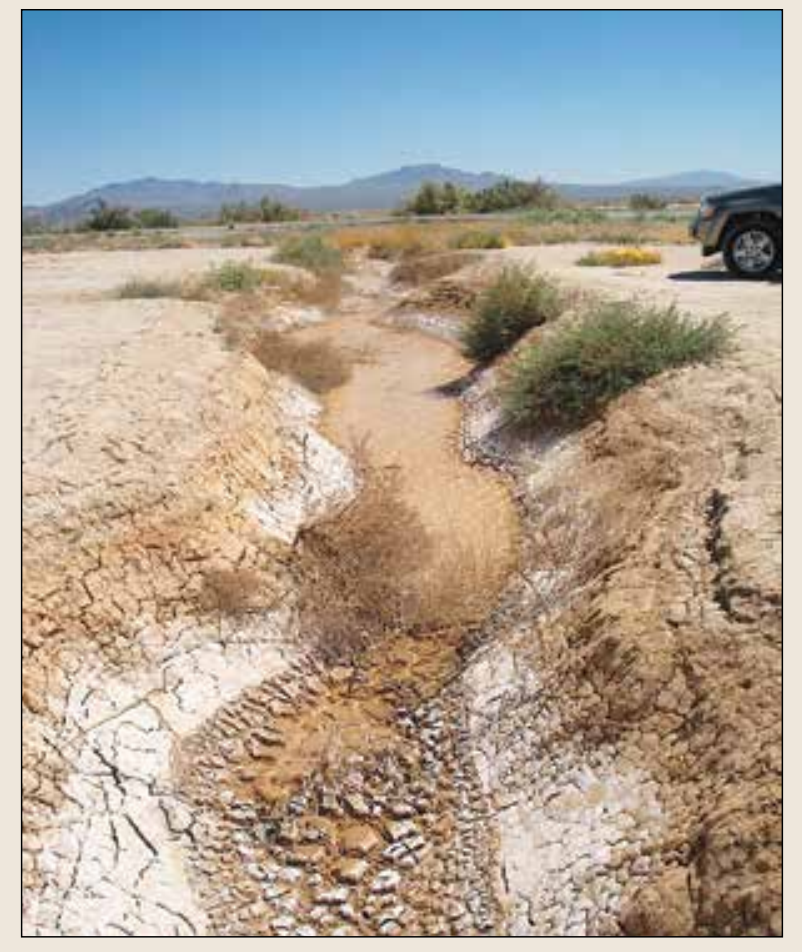

Fissure near Lucerne Lake along State Route 247 (visible in background). Photograph by Michelle Sneed, U.S. Geological Survey.
The timing of compaction associated with water-level declines is important to understand when considering subsidence management strategies. For instance, if compaction stopped soon after water levels stabilize or begin to recover (concurrent), different management strategies would be needed than if compaction continued after water levels stabilize or begin to recover (residual). Given an equivalent water-level decline, the thicker a clay deposit, the longer residual compaction is likely to continue after water levels stabilize or recover.

Integrating subsidence, groundwater level, and lithological data can help scientists discern if the subsidence is recoverable or permanent as well as if the compaction is concurrent or residual. Determining depth intervals at which water levels have declined and inter-bedded clay deposits exist provides information for targeting subsidence mitigation measures. Determining the thickness of clay deposits also is important for estimating planning horizons of mitigation measures. Furthermore, determining the historical low groundwater level will help estimate critical water-level thresholds at which permanent subsidence is likely to occur.

In the Harper, Troy, and Lucerne Lake areas, analyses indicate that both concurrent and residual compaction may have occurred and that at least some of the subsidence is permanent. In all three of these areas, determining the relative contributions of concurrent and residual compaction

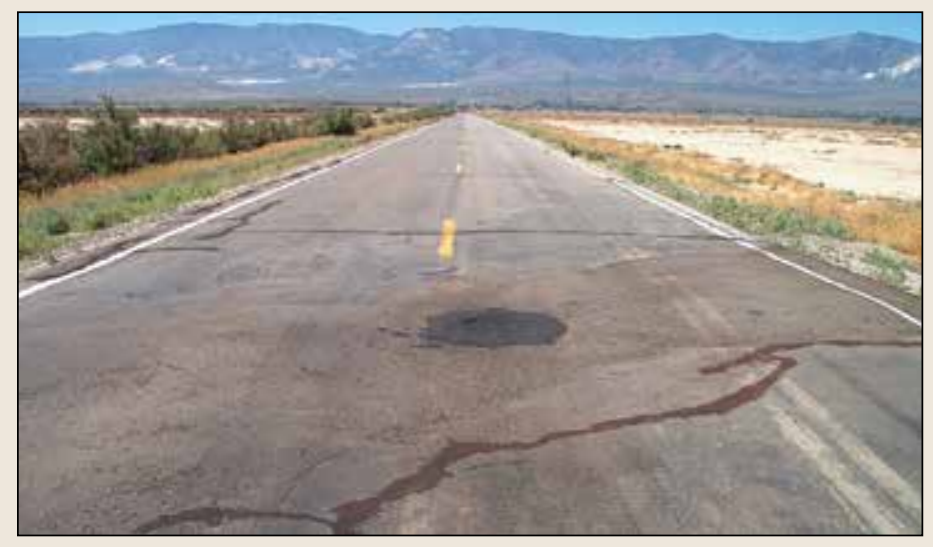

Repairs to State Route 247 after fissures near Lucerne Lake damaged the road surface. Photograph by Michelle Sneed, U.S. Geological Survey. was not possible because available data indicated persistent water-level declines in shallow wells and subsidence. Frequent measurements of water levels and subsidence under conditions that include periods of water-level recovery may improve the understanding of subsidence mechanisms - if subsidence occurs as groundwater levels recover, then it can be attributed to residual compaction.

In the El Mirage and Coyote Lake areas, less is understood about the subsidence mechanisms because less data were available. Historical (simulated) and recent (measured) waterlevel declines at El Mirage Lake indicate that at least some of the observed compaction may be permanent because water levels are likely at or near historical lows, and available lithology data suggest that concurrent and residual compaction likely occurred. Historical water-level and lithologic data were insufficient for Coyote Lake, making the subsidence mechanisms of this area the least well understood. 


\section{Future Monitoring}

It is important to continue monitoring groundwater levels and land subsidence in the southwestern Mojave Desert because water-level declines and subsidence are expected to persist. Subsidence has accelerated in some places such as near Lucerne and Troy Lakes, which in part, may reflect an increase in water use tied to changes in agricultural land use or population. InSAR can be used to develop detailed seasonal, annual, and multi-annual subsidence maps of the five areas discussed herein and to identify previously unknown subsidence throughout the nearly 5,000- $\mathrm{mi}^{2}$ MWA management area. Where detailed studies are of interest, InSAR can be used to site ground-based single or networked extensometer or Global Positioning System (GPS) monitoring stations. As of 2017, InSAR-capable satellites are routinely collecting data over the area - with additional satellites planned - making the future of InSAR data availability promising.

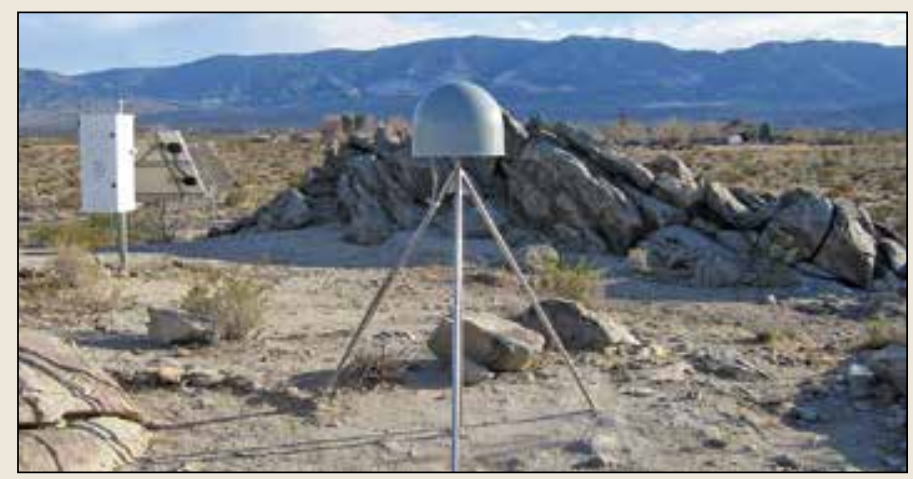

Continuous GPS (CGPS) site (P582) is one of 13 sites in the study area that collected position data in 2016 and can be used to evaluate subsidence. Daily data from a CGPS site and spatially detailed data from InSAR can be leveraged to improve the understanding of compaction processes in time and space. Photograph courtesy of University NAVSTAR Consortium (UNAVCO), copyright 2006 UNAVCO, Inc. (used with permission).

Coordinating groundwater-level and subsidence monitoring, in both time and space, could improve the understanding of the mechanisms that drive compaction. Ideally, water levels would be measured in wells (with known construction) often enough to capture water level highs and lows at seasonal, annual, and multi-annual scales, and compared to subsidence measurements at similar timescales. As new wells are drilled, detailed logging of subsurface lithology would improve the delineation of the depths and thicknesses of clay deposits. Currently (2016), 13 continuous GPS (CGPS) sites are located in the MWA management area (fig. 2), but generally are distant from areas of known subsidence, or have a period of record too limited to have been useful for the 1992-2009 study period. Extensometers currently are the only tools that can measure compaction at depth-specific intervals, and have not been installed in the MWA management area (InSAR and CGPS measure subsidence at the land surface). When coupled with co-located water-level measurements, extensometer measurements can be used to analyze the aquifer-system response to water-level changes at specific depth intervals. This information can lead to a better understanding of the storage properties of the aquifer, thereby improving simulations of groundwater flow and subsidence, and facilitate the consideration of land subsidence as a constraint in evaluation of water-resource management strategies.
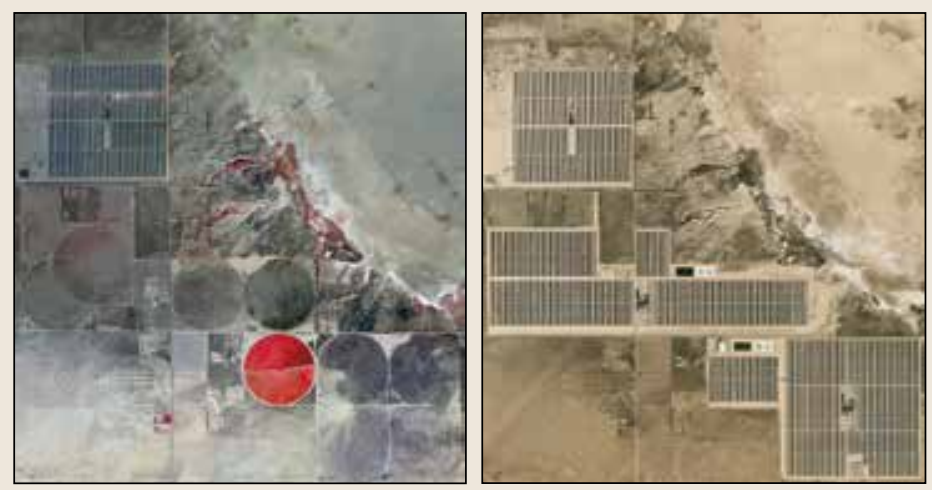

Areal imagery of the Harper Lake area showing center pivot farms in 2007 (left, near infrared false-color image) that were converted to solar fields by 2015 (right). Land-use changes such as those illustrated above require less water and may help explain some of the water-level recovery observed in this area. Images provided by Mojave Water Agency (used with permission).

\section{References Cited}

Galloway, D.L., Jones, D.R., and Ingebritsen, S.E., 1999, Land subsidence in the United States, 1999: U.S. Geological Survey Circular 1182, http://pubs.er.usgs.gov/publication/cir1182.

Motts, W.S., ed., 1969, Geology and hydrology of selected playas in Western United States: Amherst, University of Massachusetts, 305 p.

Sneed, Michelle, Ikehara, M.E., Stork, S.V., Amelung, Falk, and Galloway, D.L., 2003, Detection and measurement of land subsidence using interferometric synthetic aperture radar and global positioning system, San Bernardino County, Mojave Desert, California: U.S. Geological Survey Water-Resources Investigations Report 03-4015, $60 \mathrm{p}$.

Solt, Mike, and Sneed, Michelle, 2014, Subsidence (2004-2009) in and near lakebeds of the Mojave River and Morongo groundwater basins, southwest Mojave Desert, California: U.S. Geological Survey Scientific Investigations Report 2014-5011, unpaginated, http:// dx.doi.org/10.3133/sir20145011.

Stamos, C.L., Glockhoff, C.S., McPherson, K.R., and Julich, R.J., 2007, Water-level and land-subsidence studies in the Mojave River and Morongo groundwater basins: U.S. Geological Survey Scientific Investigations Report 2007-5097, unpaginated, http://pubs.usgs.gov/ sir/2007/5097/.

Stamos, C.L., Martin, Peter, Nishikawa, Tracy, and Cox, B.F., 2001, Simulation of ground-water flow in the Mojave River Basin, California (ver. 3, September 2001): U.S. Geological Survey WaterResources Investigations Report 2001-4002, 137 p.

\footnotetext{
Authors: Justin Brandt and Michelle Sneed

For more information: U.S. Geological Survey 6000 J Street, Placer Hall, California State University, Sacramento Sacramento, CA 95819 https://ca.water.usgs.gov/mojave
}

Publishing support provided by the U.S. Geological Survey, Tacoma Publishing Service Center

Design: William Gibbs 